\title{
Safety Evaluation of an Anti-Tumor Necrosis Factor-Alpha Receptor Fusion Protein in Sprague Dawley Rats
}

\author{
G. Selvam $^{1 *}$, S. Bhuvana ${ }^{2}$, P.C. Prabu ${ }^{3}$ and K. Sadasivan Pillai ${ }^{1}$ \\ ${ }^{1}$ University of Madras, Chepauk, Chennai - 600 005, India \\ ${ }^{2}$ Department of Academics and Human Resource Development, Indian Institute of Food \\ Processing Technology, Thanjavur - 613 005, India \\ ${ }^{3}$ Department of Veterinary Pathology, Madras Veterinary College, Tamilnadu Veterinary and \\ Animal Sciences University, Chennai - 600 007, India \\ *Corresponding author
}

\section{A B S T R A C T}

\section{Keywords}

Anti TNF- $\alpha$

receptor fusion

protein,

biopharmaceuticals, toxicity, preclinical safety, rats

\section{Article Info}

Accepted:

05 May 2020

Available Online:

10 June 2020
Preclinical safety evaluation of a biopharmaceutical agent is highly essential to identify and define the toxicity profile of the agent. The present study was carried out on Sprague Dawley rats to evaluate the sub-acute toxicity of an anti - tumor necrosis factor -alpha receptor fusion protein named etanercept. Etanercept is a biopharmaceutical compound and is the first anti-tumor necrosis factor agent to be approved for the treatment of rheumatoid arthritis. To simulate the human intended route, the etanercept was administered through the subcutaneous route for a period of 28 days with a 14 days of recovery period for high dose alone. To evaluate the safety margin in the pre-clinical setup, the dose levels were selected approximately 1,5 and 10 times of the human equivalent dose (HED).No morbidity, mortality and clinical signs of toxicity were observed in the animals belonging to the control groups as well as the test substance treated groups throughout the observation period. The in-life data like, body weight gain,feed consumption and water consumption revealed no significant difference in comparison between the treated and their concurrent control animals. Hematology and biochemical examinations did not show significant changes in all the treated groups in comparison with their concurrent control groups. No test substance related changes were observed in absolute and relative organ weights of both the sexes of treated animals. No test substance related gross pathological findings were observed in animals treated with test substance. As the test substance did not produce any significant adverse effect, the high dose i.e. $52 \mathrm{mg} / \mathrm{kg} \mathrm{b}$.w. was concluded as no-observed-adverse-effect level (NOAEL) for etanercept in the Sprague Dawley rats through subcutaneous route.

\section{Introduction}

Biopharmaceuticals are human proteins which are produced in cells utilizing DNA technology. Conventionally, biopharma- ceuticals consist of recombinant forms of endogenous human proteins meant for replacement therapy or monoclonal antibodies (mAbs) and soluble 'decoy' receptors which block the pharmacological effects of 
endogenous human proteins or pathogens (Walsh, 2010). Etanercept is a biopharmaceutical compound and is the first anti-tumor necrosis factor agent to be approved for the treatment of rheumatoid arthritis (Haraoui and Bykerk, 2007). It is a dimeric human tumor necrosis factor receptor 2 (TNFR2 or p75TNFR) -Fc fusion protein, which is genetically engineered by recombinant DNA technology in Chinese hamster ovary (Weinblatt et al., 1999). It is made-up of two extracellular domains of the human 75kD TNFR (i.e. p75TNFR) coupled with a constant $\mathrm{Fc}$ portion of human immunoglobulin 1 (IgG1) (Haraoui and Bykerk, 2007; Bradley, 2008; Martin and Bugelski, 2012). In-vitro and in-vivo studies have proved that etanercept competitively binds with the cellular transmembrane TNFRs and thus, renders both the TNF- $\alpha$ and TNF- $\beta$ biologically inactive (Mohler et al., 1993). Etanercept is effective for treating rheumatoid arthritis, juvenile idiopathic arthritis, psoriatic arthritis, axial spondylo-arthritis, ankylosing spondylitis, non-radiographic axial spondyloarthritis, plaque psoriasis and paediatric plaque psoriasis (Bradley, 2008; Aggarwal et al., 2011).

Development of biopharmaceuticals involves highly complex engineering technologies. The diverse recombinant cell systems utilized for the generation of the biopharmaceuticals and other technical and scientific flaws during the manufacture often leads to a greater risk of failure of a biopharmaceutical agent (Meena et al., 2008; Lynch et al., 2009). In addition, safety issues might arise due to the impurities as well as other contaminants present in the final product. Preclinical safety evaluation of a biopharmaceutical agent is highly essential to identify and define the toxicity profile of the agent in question and to provide information on the quality controls applied during product development apart from the identification of unexpected target organ toxicity and its reversibility, identification of safe starting dose and subsequent dose escalation for conducting clinical trials in human (Lynch et al., 2009, ICH, 2011). The present study was carried out on Sprague Dawley rats to evaluate the sub-acute toxicity potential and to ascertain the no-observedadverse-effect-level (NOAEL) of etanercept.

\section{Materials and Methods}

\section{Animal Welfare}

The study was conducted at International Institute of Biotechnology and Toxicology, Padappai which is recognized under the Committee for the Purpose of Control and Supervision of Experiments on Animals (CPCSEA), Ministry of Forest and Environment, Govt. of India for breeding and conducting experiments on animals. The animals were handled with utmost care and the experimental procedures were carried out on the selected test system (Sprague Dawley rats) humanely at every step, in accordance with the CPCSEA guidelines. Prior to conduct of the study approvals from Institutional Animal Ethics Committee (IAEC) and Institutional Bio-safety Committee (IBSC) were obtained.

\section{Identification of animals and acclimatization}

Cage cards marked with study number, cage number, animal number, sex, group number, test substance name, dose level and date were attached to cages. Each animal was given a unique number and identified by ear-tagging. After randomization and individual identification, the animals were kept in their cages at the experimental room for 5 days prior to the start of the experiment to allow them to acclimatize with the laboratory conditions. 


\section{Animal Husbandry}

During the whole experimentation, the experimental room temperature was maintained between 20 and $22^{\circ} \mathrm{C}$ and the relative humidity between 50 and $60 \%$. Temperature and relative humidity were monitored once daily. The experimental room was provided with a $12 \mathrm{~h}$ light and $12 \mathrm{~h}$ dark photoperiod cycle controlled by an automatic timer. Test room light intensity and the noise level were maintained within 100 lux and $50 \mathrm{db}$, respectively. Standard polypropylene rat cages with stainless steel top grill supplied by M/s. Vishnu Traders, UP, India were used to house the animals. Each cage contained 4 males or 4 females. The cages and grills were autoclaved prior to the usage. Gamma irradiated corn cob was used as the bedding material. Bedding material, cages and grills were changed on alternate days. Fresh drinking water was provided every day. Gamma irradiated rodent pellet feed supplied by M/s. Tetragon Chemie Pvt. Ltd., Bangalore and clean reverse osmosis purified drinking water were provided to the animals at ad libitum. Feed alone was withdrawn for overnight fasting prior to blood collection.

\section{Randomization}

After receiving, the animals were assigned to various groups using a randomization procedure. This procedure involved assigning serial numbers to animals, generating random numbers from scientific calculator, ranking random numbers and assigning the animals to six groups (G1, G2, G3 G4, G1R and G4R) having 8 males and 8 females in each group.

\section{Preparation of the Test Substance}

Prior to the subcutaneous dosing to the treatment group rats, the test substance was reconstituted with formulation buffer.

\section{Experimental Design, Dose levels and} Route of Administration of Test Substance

The selected dose levels were approximately 1,5 and 10 times of the human equivalent dose (HED). The volume of doses administered was maintained at $2.5 \mathrm{ml} / \mathrm{kg}$ b.w. in all the groups. The test substance (etanercept) was reconstituted with formulation buffer (vehicle) and was administered every third day for a period of 28 days by subcutaneous injection using disposable syringes for the animals belonging to G2, G3, G4 and G4R groups at the dose rate mentioned in Table 1. The control group (G1 and G1R) animals were treated only with the formulation buffer through subcutaneous route. The reversal groups (G1R and G4R) were included to identify the reversibility of the clinical signs or lesions, if any. Subcutaneous route was selected, since it is one of the intended routes of administration in humans.

\section{Observations}

\section{Morbidity / Mortality}

Animals of all groups (G1, G2, G3, G4, G1R and G4R) were observed for morbidity and or mortality once daily for a period of 28 days. The observation period was extended for another 14 days for the reversal groups (G1R and G4R) to identify the reversibility of the test substance induced clinical signs of toxicity, if any.

\section{Toxicity Signs}

The animals were monitored for the exhibition of clinical signs of toxicity at 1,2 , 3 and 4 hours after dosing and once daily throughout the observation period of 28 days for G1, G2, G3 and G4 and 42 days for G1R and G4R animals. All the animals were observed individually for toxicity signs viz. 
hemorrhage, edema, eschar and necrosis at the site of test substance administration; hypersensitivity reactions like, fur shed, alopecia, excessive salivation, conjunctivitis, lacrimation, dermatitis with erythema, eschar, papular and vesicular lesions at skin surface and nasal irritation; neurologic signs like, coma, convulsion, hyperesthesia, ataxia, catalepsy, circling, abnormal behaviors, paralysis, tremors etc.; respiratory signs like dyspnea, bradypnea, tachypnea, unusual respiratory sounds and nasal discharges; and general disease signs like, prostration, dullness, depression, anorexia and or inaniation, hunched back, piloerection, prostration, polyuria, polydipsia and death.

\section{Body weight, feed and water consumption}

Body weight of each animal was recorded just prior to administration of dose (day 1) and on every third day following the initial dosing. Cage-wise feed consumption was recorded once daily. Cage-wise water consumption was recorded once daily.

\section{Clinical Pathology}

Blood was collected from all the groups of animals on the day before dosing (day 0), day 29 and day 43 [from reversal groups (G1R and G4R)]. Prior to the blood collection, the animals were fasted overnight. The blood was collected from the retro-orbital plexus in EDTA coated vials for hematology and in heparinized vials for biochemistry. The clotting time and prothrombin time were performed by following Wrighting's method using Sabraze's capillary tube and one stage prothrombin time method, respectively. Other hematological parameters were analyzed using Hematology Bayer Advia $120^{\mathrm{TM}}$ fully automated analyzer. The clinical chemistry parameters were analyzed using Human Humastar 300 fully automated biochemistry analyzer.

\section{Anatomic Pathology}

\section{Organ Weight}

The absolute organ weights were measured and the relative organ weights were calculated for the following organs:Brain, lungs, heart, liver, spleen, adrenals, gonads and uteri.

\section{Gross Pathology}

At the end of the observation period (i.e. $29^{\text {th }}$ day for G1 to G4 groups; $43^{\text {rd }}$ day for G1R and G4R groups), the animals were euthanized by $\mathrm{CO}_{2}$ exposure. A detailed gross pathology examination was carried out on all the animals. After examination of the external appearance, the cranial, thoracic and abdominal cavities were opened and the structural abnormalities, if present were recorded for each animal.

\section{Histopathology}

The below mentioned organs and tissues of both the groups were collected, preserved in $10 \%$ neutral buffered formalin. The testes were preserved in modified Davidson's fixative and the lungs were inflated with the fixative before preservation. After adequate fixation, the following organs were trimmed appropriately, dehydrated by passing through ascending series of alcohol at specific time intervals, cleared with xylene, infiltrated and embedded with paraffin wax, sectioned at 3 $5 \mu \mathrm{m}$ thick and stained with haematoxylin and eosin: Injection site, brain, liver, lung, kidneys, urinary bladder, oesophagus, stomach, small intestines, large intestines, heart and aorta, spleen, thymus, adrenals, thyroid, knee joint, gonads and uteri.

The histopathology glass slides were screened for the presence of test substance induced structural changes by using Nikon $50 i^{\mathrm{TM}}$ microscopes at suitable magnification. The 
gross and histopathology findings were summarized group-wise.

\section{Statistical Analysis}

The data of body weights, feed consumption, water consumption, organ weights, functional observational battery, hematology and biochemistry was subjected to modified Levene equal variance test for homogeneity using Number Cruncher Statistical Software 2007. Homogenous data was submitted to Student's ' $t$ '-test / analysis of variance (ANOVA) using NCSS software followed. If ANOVA showed significant result, StudentNewman-Keul's test was used for post hoc comparison. High dose reversal and control reversal groups were compared by using Student's ' $t$ ' - test.

\section{Results and Discussion}

\section{Morbidity / Mortality}

No morbidity/mortality was observed in the animals belonging to the control groups (G1 and G1R) as well as the test substance treated groups (G2, G3, G4 and G4R) throughout the observation period.

\section{Toxicity Signs}

No clinical signs of toxicity were observed in the animals belonging to the control groups (G1 and G1R) as well as the test substance treated groups (G2, G3, G4 and G4R) throughout the observation period.

\section{Body weight}

In comparison with concurrent control, male animals belonging to G3 and G4 showed significant increase in bodyweight on days 4 and 7, respectively. However, the males of G4 and G4R showed statistically significant decrease in body weight on day 28 and day
43, respectively. Likewise, in comparison with concurrent control, the females belonging to $\mathrm{G} 2$ and G4R showed significant decrease in bodyweight on day 25 and day 43, respectively (Figures 1 and 2).

\section{Feed Consumption}

There was no statistically significant difference observed in feed consumption in males of G2, G3 and G4 groups when compared with control males (G1). Males of G4R showed a significant increase in feed consumption on $2^{\text {nd }}$ and $3^{\text {rd }}$ weeks in comparison with males of control reversal (G1R). Females of G2 showed a significant decrease in feed consumption during $1^{\text {st }}$ week, when compared with control females (G1). As these changes were not consistent, they cannot be related to test substance. There is no significant difference in the feed consumption of G4R group animals when compared with animals of control reversal (G1R) (Figures 3 and 4).

\section{Water Consumption}

Water consumption in males of G2, G3 and G4 groups was normal and consistent when compared with control males (G1). There was no significant difference in the water consumption of G4R males when compared with control reversal males (G1R). Females belonging to $\mathrm{G} 3$ showed significant increase in water consumption at $2^{\text {nd }}$ week when compared with control females (G1). Females belonging to G4R showed significant increase in water consumption at $2^{\text {nd }}$ week when compared with females of control reversal females (G1R) (Figures 5 and 6).

\section{Clinical Pathology}

\section{Hematology and Biochemical Analysis}

Hematology examinations performed on days 
0,29 and 43 did not show significant changes in all the treated groups (G2, G3, G4 and G4R) in comparison with their concurrent control groups. Biochemistry examinations performed on days 0, 29 and 43 did not show significant changes in all the treated groups (G2, G3, G4 and G4R) in comparison with their concurrent control groups.

\section{Anatomic Pathology}

No test substance related changes were observed in absolute (Table $2 \& 3$ ) and relative (data not shown) organ weights of both the sexes of treated animals (G2, G3 and G4), when compared that of the control animals (G1). Similarly, both the males and females of the treated reversal group (G4R) did not show any significant change in absolute and relative organ weights when compared with that of the reversal control group (G1R). No test substance related gross pathological findings (Table 4) were observed in animals treated with test substance (G2, G3, G4 and G4R). Similarly, control group (G1 and G1R) animals administered with formulation buffer did not show any gross pathological findings. The findings like, white foci and diaphragmatic nodule in liver and enlargement of unilateral kidney were observed sporadically in control and treated groups without any dose dependency and consistency. These gross findings were either related to incidental (white foci in liver), spontaneous (enlargement of kidney) or congenital (diaphragmatic nodule in liver) and of the type routinely observed in Sprague Dawley rats of this age.

\section{Histopathology}

No test substance related histopathological findings (Table 5) were observed in animals treated with test substance (G2, G3, G4 and G4R). Similarly, control group (G1 and G1R) animals administered with formulation buffer did not show any histopathological findings.
All microscopic findings were either related to agonal, to spontaneous, to physiological or were incidental and of the type routinely observed in Sprague Dawley rats of this age.

Chronic inflammatory diseases like rheumatoid arthritis, systemic lupus erythematosus, multiple sclerosis and many others are a burden to humans because of lifelong debilitating illness, increased mortality and high costs for therapy and care (Straub and Schradin, 2016). These are a group of common and highly disabling chronic conditions that share inflammatory pathways. As a part of safety pharmacology testing procedures, pre-clinical repeated dose toxicity studies of biopharmaceuticals are conducted with the test substance at 3 different dose levels administered through the route that is clinically intended in humans. TNF has been implicated in the pathogenesis of several non-infectious conditions including rheumatoid arthritis (Saxne et al., 1988) and multiple sclerosis (Sharief and Hentges, 1991). It is released by the leukocytes in certain conditions of the heart resulting in myocardial damage (Natanson et al., 1989). Increased blood levels of TNF $\alpha$ has been observed in individuals with cardiomyopathy, myocardial infarction and chronic heart failure (Levine et al., 1990) confirming its role in these diseases.

TNF inhibitors are highly effective in treating RA and IBD. The key role of tumor necrosis factor in inflammation has been confirmed by the effectiveness of the compounds which inhibit the activity of TNF in the management of several inflammatory disorders like rheumatoid arthritis, ankylosing spondylitis, inflammatory bowel disease and psoriasis. The TNF superfamily of cytokines consists of a multivariate class of cytokines that promote inflammation, by activating signal transduction pathways involved in cellular survival, programmed cell death, inflammation as well as cell differentiation. 


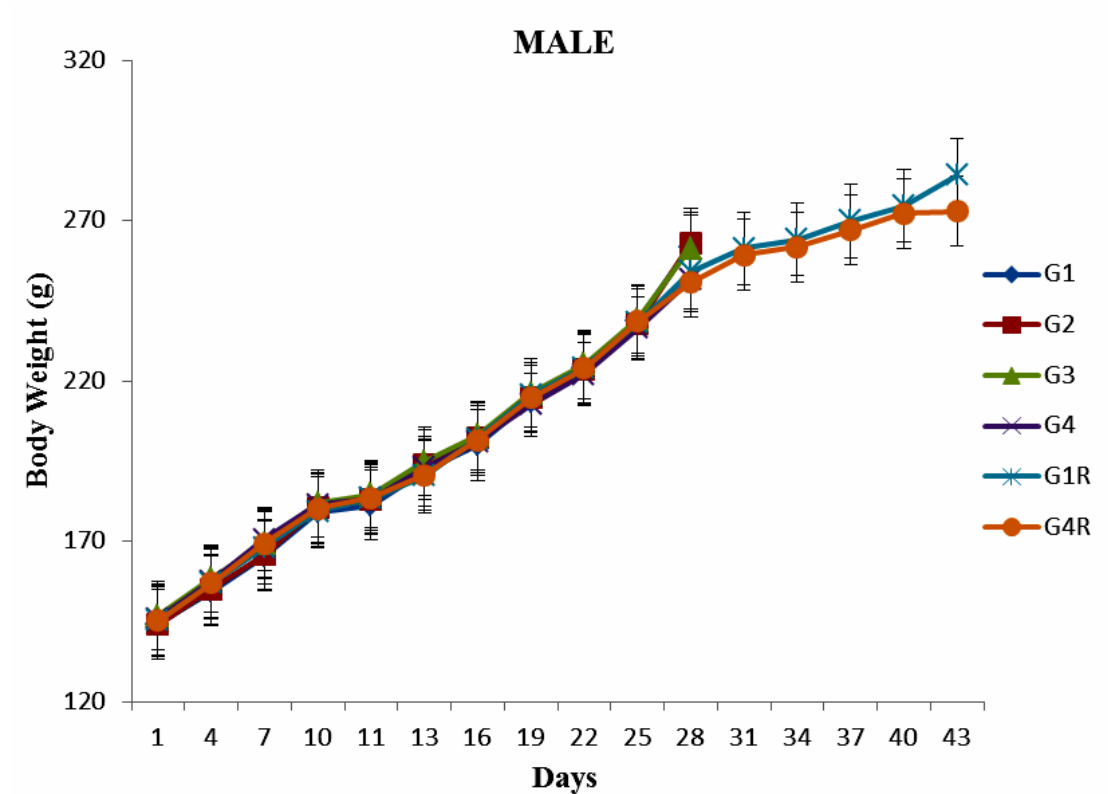

Figure.1 Body weight of male rats of control (G1 and G1R) and male rats treated (G2, G3, G4 and G4R) repeatedly with etanercept through subcutaneous route. (Values represent the mean and vertical bars indicate the standard error $(n=8))$.

\section{FEMALE}

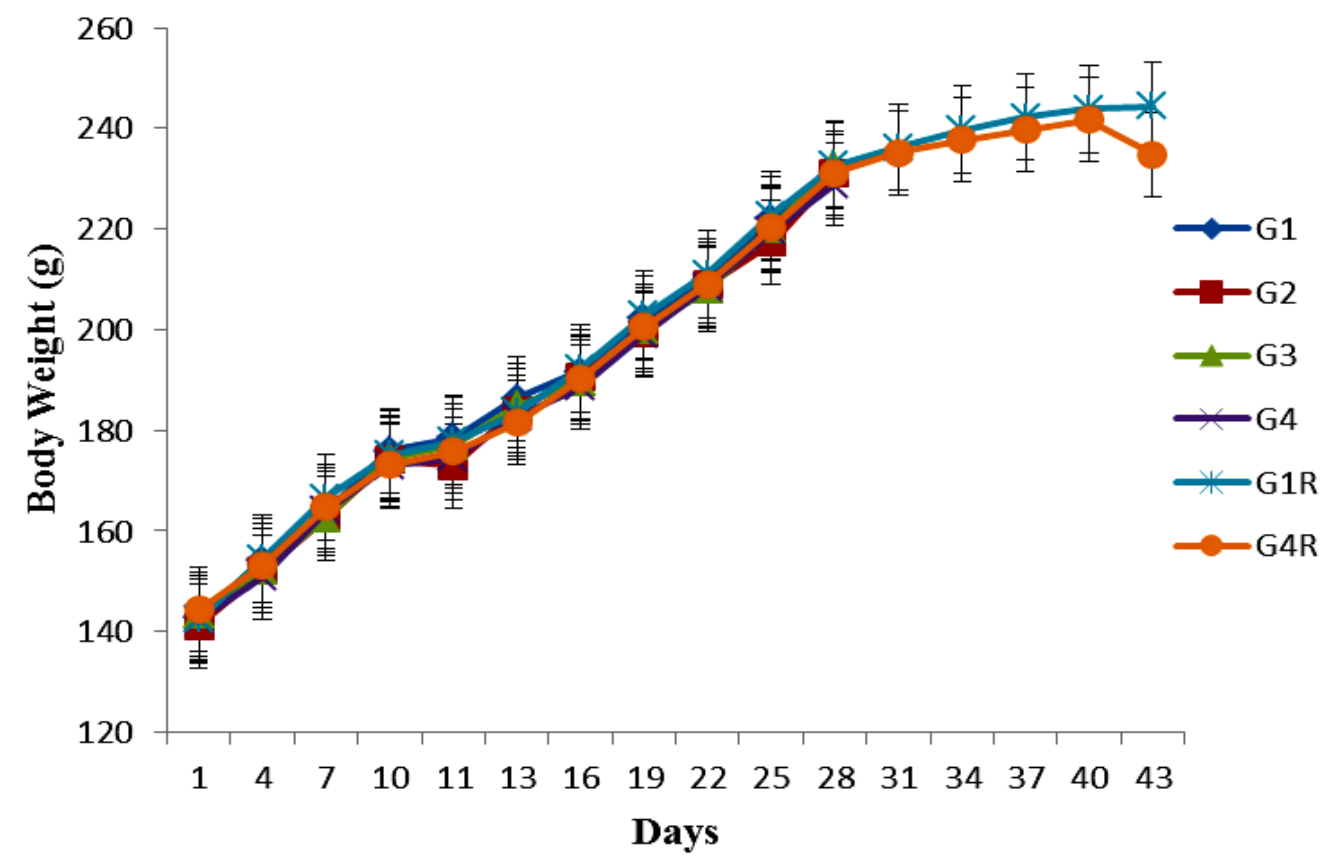

Figure.2 Body weight of female rats of control (G1 and G1R) and female rats treated (G2, G3, G4 and G4R) repeatedly with etanercept through subcutaneous route. (Values represent the mean and vertical bars indicate the standard error $(n=8)$ ). 


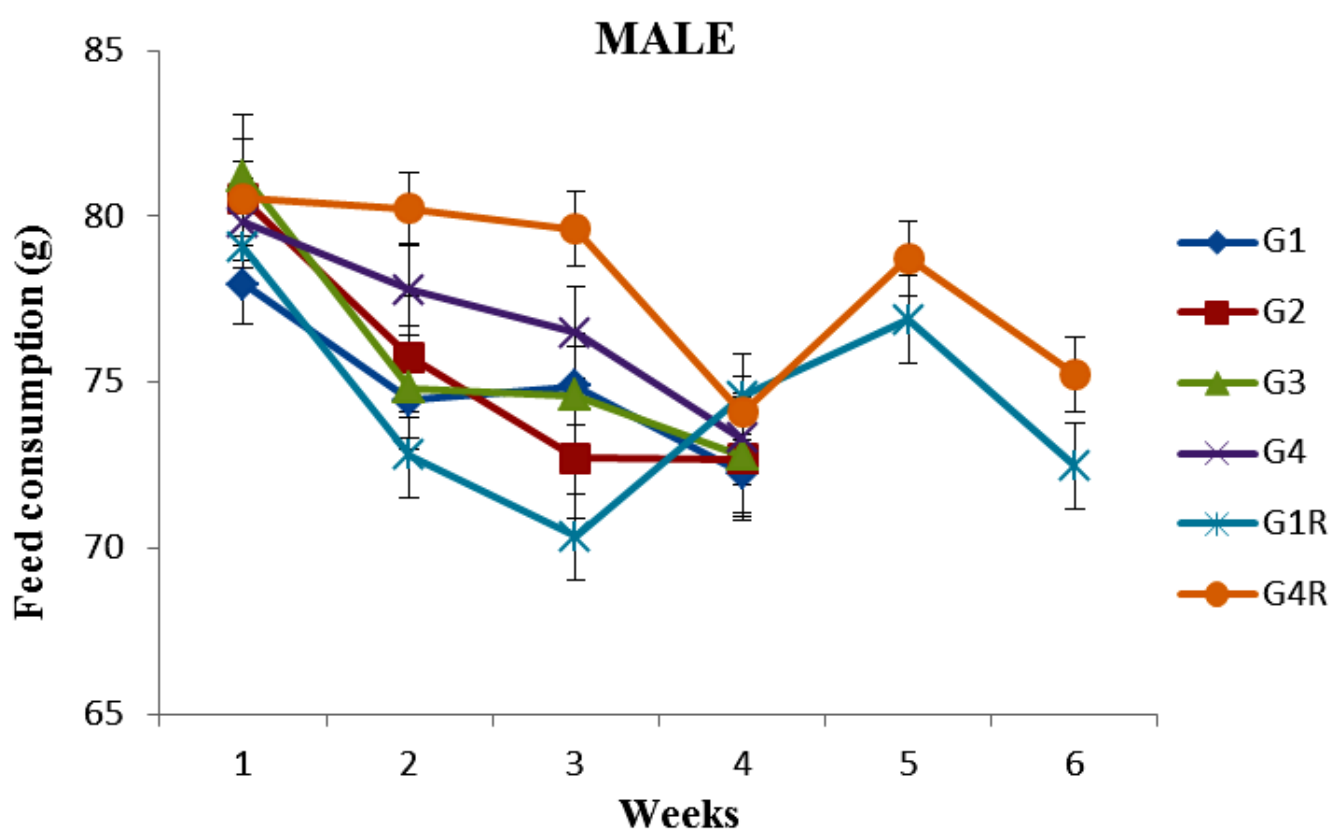

Figure.3 Feed consumption of male rats of control (G1 and G1R) and male rats treated (G2, G3, G4 and G4R) repeatedly with etanercept through subcutaneous route. (Values represent the mean of cage-wise feed consumption per animal in a week and vertical bars indicate the standard error (number of cages $=2$ ). Comparison was made week-wise. Feed consumption is not statistically different at 5\% probability level (Student's t test)).

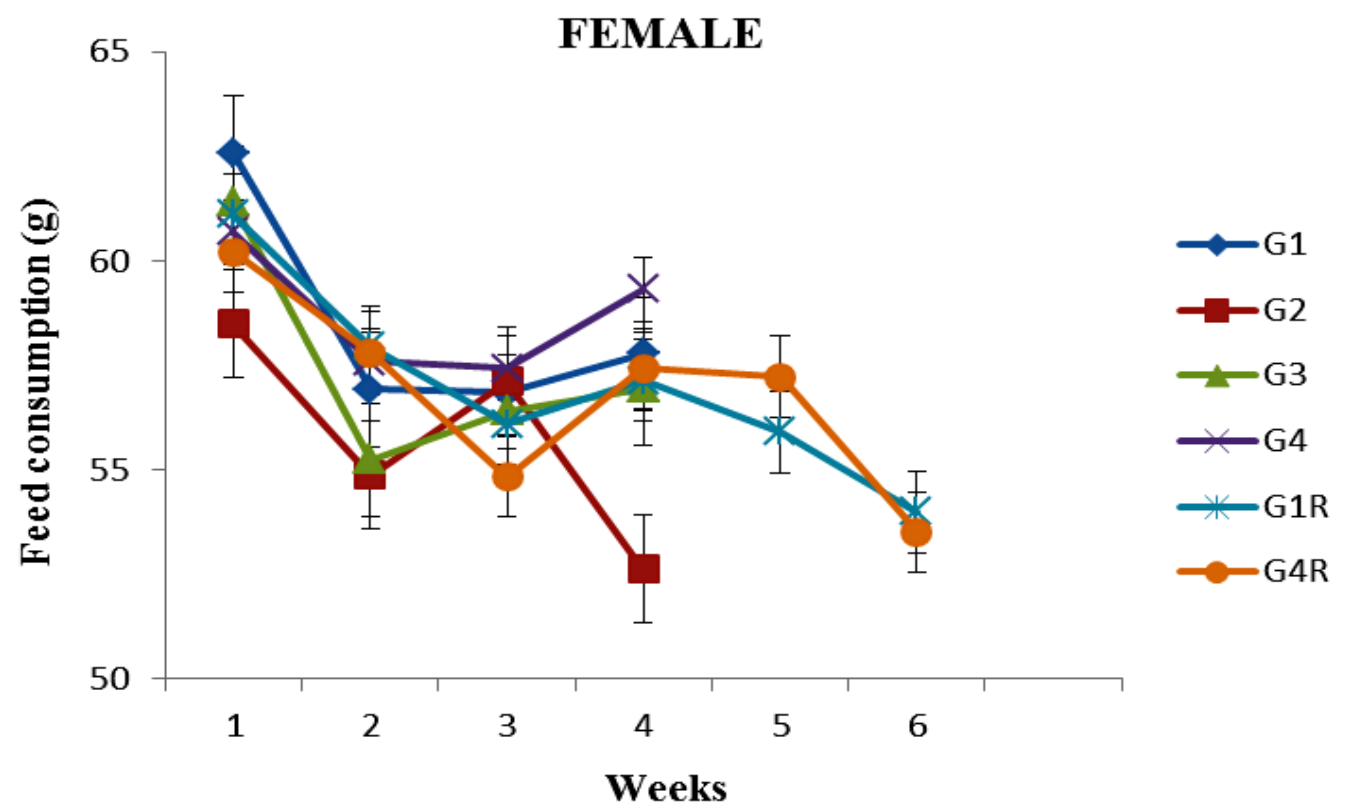

Figure.4Feed consumption of female rats of control (G1 and G1R) and female rats treated (G2, G3, G4 and G4R) repeatedly with etanercept through subcutaneous route. (Values represent the mean of cage-wise feed consumption per animal in a week and vertical bars indicate the standard error (number of cages $=2$ ). Comparison was made week-wise. Feed consumption is not statistically different at 5\% probability level (Student's t test)). 


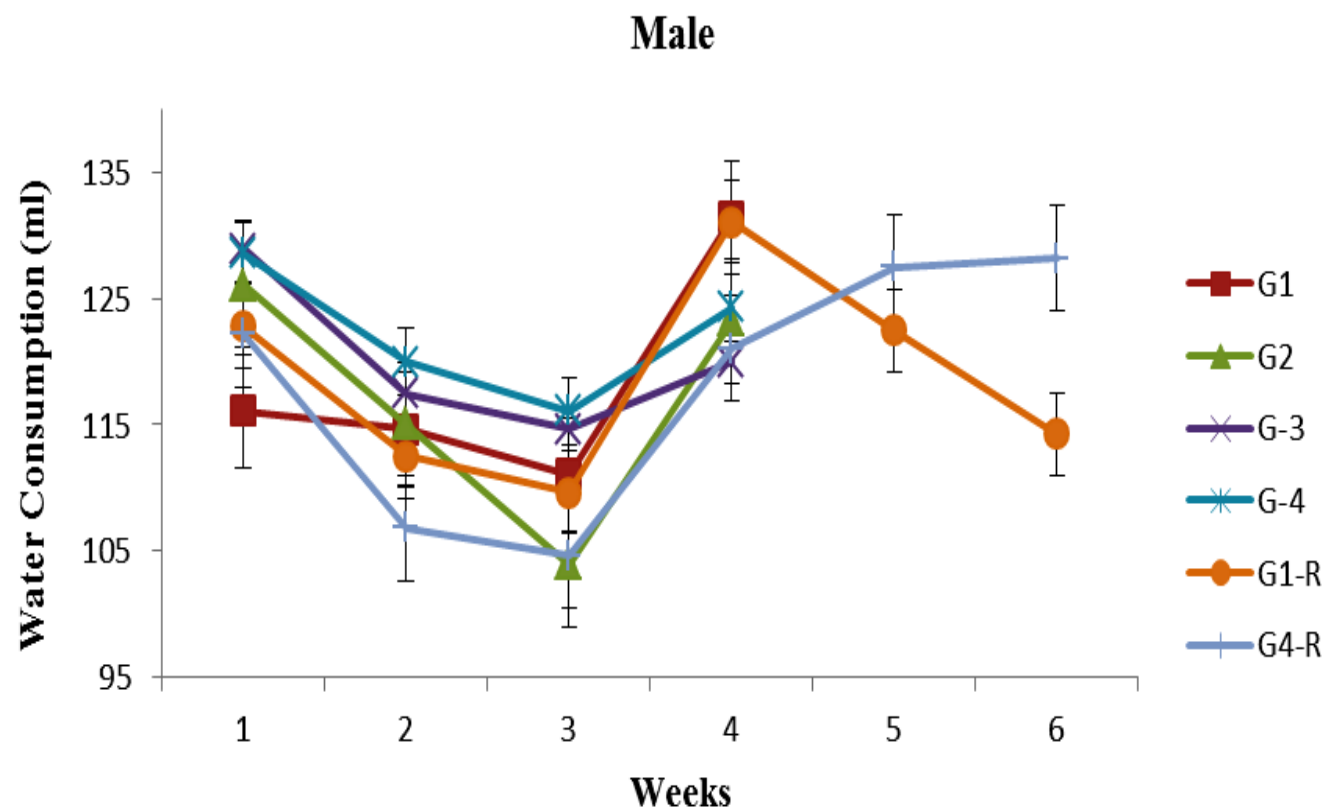

Figure.5Water consumption of male rats of control (G1 and G1R) and male rats treated (G2, G3, G4 and G4R) repeatedly with etanercept through subcutaneous route. (Values represent the mean of cage-wise water consumption per animal in a week and vertical bars indicate the standard error (number of cages = 2). Comparison was made week-wise. Water consumption is not statistically different at 5\% probability level (Student's t test)).

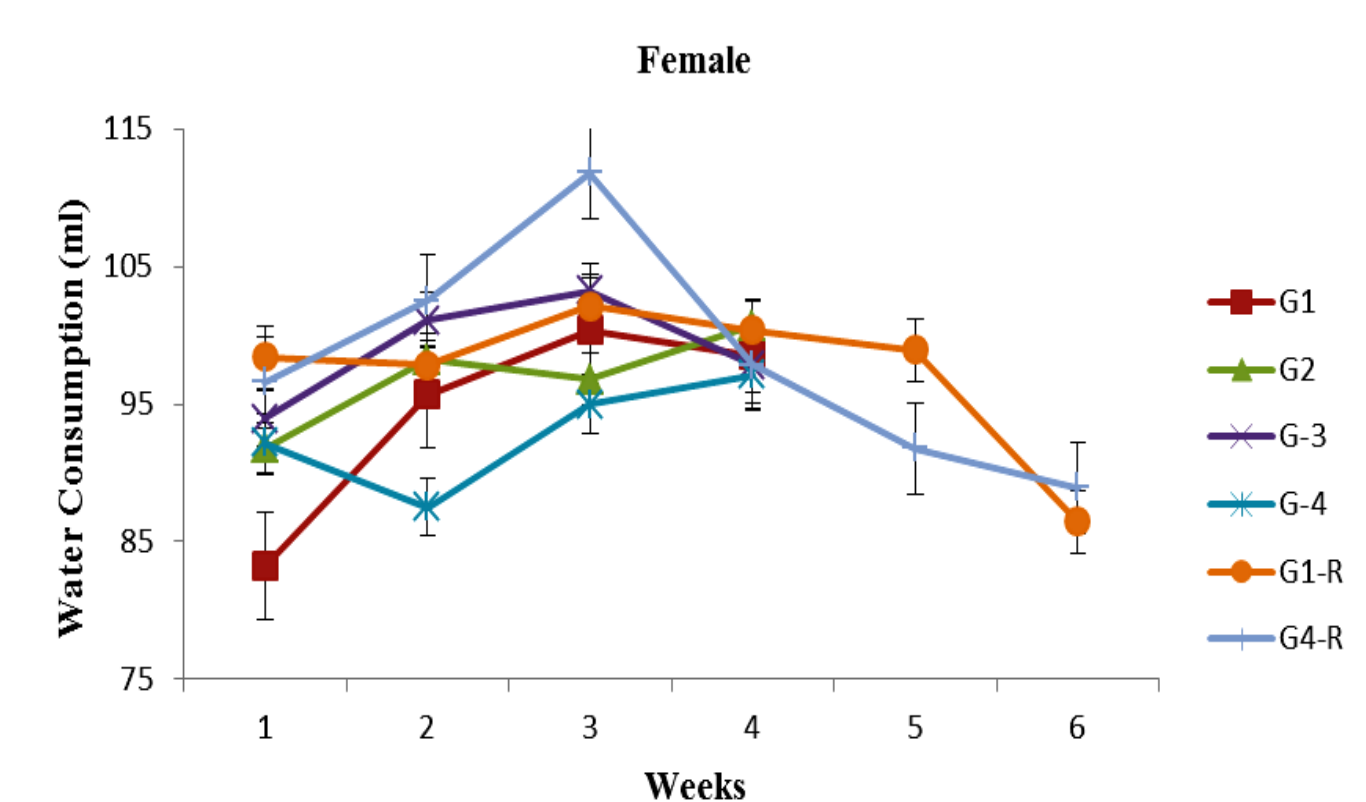

Figure.6Water consumption of female rats of control (G1 and G1R) and female rats treated (G2, G3, G4 and G4R) repeatedly with etanercept through subcutaneous route. (Values represent the mean of cage-wise water consumption per animal in a week and vertical bars indicate the standard error (number of cages $=2$ ). Comparison was made week-wise. Water consumption is not statistically different at 5\% probability level (Student's t test)). 
Table.1 Experimental Design and Dosage Regimen

\begin{tabular}{|c|c|c|c|c|}
\hline \multirow{2}{*}{$\begin{array}{l}\text { Group } \\
\text { Number }\end{array}$} & \multirow[t]{2}{*}{ Treatment } & \multirow{2}{*}{$\begin{array}{c}\text { Dose } \\
(\mathrm{mg} / \mathrm{kg} \mathrm{b.w.)}\end{array}$} & \multicolumn{2}{|c|}{ No. of animals } \\
\hline & & & Male & Female \\
\hline G1 & Control (FB) & 0 & 8 & 8 \\
\hline G2 & Low dose (Etanercept @ 1×HED) & 5.2 & 8 & 8 \\
\hline G3 & Mid dose (Etanercept @ 5×HED) & 26 & 8 & 8 \\
\hline G4 & High dose (Etanercept @ 10×HED) & 52 & 8 & 8 \\
\hline G1R & Control - Reversal (FB) & 0 & 8 & 8 \\
\hline G4R & $\begin{array}{c}\text { High dose - Reversal } \\
\text { (Etanercept @ 10×HED) }\end{array}$ & 52 & 8 & 8 \\
\hline
\end{tabular}

FB - Formulation buffer; HED - Human equivalent dose

Table.2 Summary of Absolute Organ Weight of Males

\begin{tabular}{|c|c|c|c|c|c|c|c|c|}
\hline GROUP & $\begin{array}{c}\text { Body } \\
\text { Weight }\end{array}$ & Brain & Liver & Spleen & Heart & Adrenals & Gonads & Lungs \\
\hline $\begin{array}{c}\text { G1 } \\
\text { (Formulation buffer) }\end{array}$ & $\begin{array}{c}261.000 \\
\pm \\
1.427 \\
\end{array}$ & $\begin{array}{c}1.973 \\
\pm \\
0.029 \\
\end{array}$ & $\begin{array}{c}12.762 \\
\pm \\
0.339 \\
\end{array}$ & $\begin{array}{c}0.561 \\
\pm \\
0.024 \\
\end{array}$ & $\begin{array}{c}1.139 \\
\pm \\
0.026 \\
\end{array}$ & $\begin{array}{c}0.052 \\
\pm \\
\pm .002 \\
\end{array}$ & $\begin{array}{c}2.725 \\
\pm \\
0.067 \\
\end{array}$ & $\begin{array}{c}1.665 \\
\pm \\
0.064 \\
\end{array}$ \\
\hline $\begin{array}{c}\text { G2 } \\
(\text { Etanercept } @ 5.2 \mathrm{mg} / \mathrm{kg} \mathrm{b.w}) \\
(1 \times \mathrm{HED})\end{array}$ & $\begin{array}{c}262.250 \\
\pm \\
1.130\end{array}$ & $\begin{array}{c}2.027 \\
\pm \\
\pm 0.034 \\
\end{array}$ & $\begin{array}{l}12.781 \\
\pm \\
0.350 \\
\end{array}$ & $\begin{array}{l}0.562 \\
\pm \\
0.010\end{array}$ & $\begin{array}{c}1.167 \\
\pm \\
0.003\end{array}$ & $\begin{array}{c}0.055 \\
\pm \\
\pm \\
0.004 \\
\end{array}$ & $\begin{array}{l}2.738 \\
\pm \\
0.045\end{array}$ & $\begin{array}{c}1.644 \\
\pm \\
0.044\end{array}$ \\
\hline 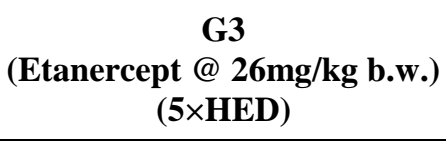 & $\begin{array}{c}261.000 \\
\pm \\
0.824\end{array}$ & $\begin{array}{c}1.980 \\
\pm \\
0.036 \\
\end{array}$ & $\begin{array}{c}13.267 \\
\pm \\
0.372 \\
\end{array}$ & $\begin{array}{c}0.556 \\
\pm \\
0.012 \\
\end{array}$ & $\begin{array}{c}1.169 \\
\pm \\
0.027 \\
\end{array}$ & $\begin{array}{c}0.050 \\
\pm \\
0.003 \\
\end{array}$ & $\begin{array}{l}2.746 \\
\pm \\
0.055\end{array}$ & $\begin{array}{c}1.837 \\
\pm \\
0.090\end{array}$ \\
\hline $\begin{array}{c}\text { G4 } \\
(\text { Etanercept @ 52mg/kg b.w.) } \\
(10 \times \text { HED })\end{array}$ & $\begin{array}{c}251.375 \\
\pm \\
1.164\end{array}$ & $\begin{array}{c}1.989 \\
\pm \\
0.028 \\
\end{array}$ & $\begin{array}{c}13.511 \\
\pm \\
0.546 \\
\end{array}$ & $\begin{array}{c}0.544 \\
\pm \\
0.018 \\
\end{array}$ & $\begin{array}{c}1.169 \\
\pm \\
0.019 \\
\end{array}$ & $\begin{array}{c}0.058 \\
\pm \\
\pm \\
0.005\end{array}$ & $\begin{array}{c}2.657 \\
\pm \\
\pm .033\end{array}$ & $\begin{array}{c}1.682 \\
\pm \\
0.051 \\
\end{array}$ \\
\hline $\begin{array}{c}\text { G1R } \\
\text { (Formulation buffer) }\end{array}$ & $\begin{array}{c}284.250 \\
\pm \\
1.333\end{array}$ & $\begin{array}{c}2.062 \\
\pm \\
0.033 \\
\end{array}$ & $\begin{array}{c}14.061 \\
\pm \\
0.336 \\
\end{array}$ & $\begin{array}{c}0.669 \\
\pm \\
0.119 \\
\end{array}$ & $\begin{array}{c}1.210 \\
\pm \\
0.035 \\
\end{array}$ & $\begin{array}{c}0.057 \\
\pm \\
\pm \\
0.005\end{array}$ & $\begin{array}{c}2.938 \\
\pm \\
0.039 \\
\end{array}$ & $\begin{array}{c}1.999 \\
\pm \\
0.168 \\
\end{array}$ \\
\hline $\begin{array}{c}\text { G4 R } \\
(\text { Etanercept @ 52mg/kg b.w.) } \\
(10 \times \text { HED })\end{array}$ & $\begin{array}{c}272.875 \\
\pm \\
1.274 \\
\end{array}$ & $\begin{array}{c}2.053 \\
\pm \\
0.026 \\
\end{array}$ & $\begin{array}{c}14.155 \\
\pm \\
0.351 \\
\end{array}$ & $\begin{array}{c}0.598 \\
\pm \\
0.024 \\
\end{array}$ & $\begin{array}{c}1.152 \\
\pm \\
0.014\end{array}$ & $\begin{array}{c}0.063 \\
\pm \\
\pm \\
0.003 \\
\end{array}$ & $\begin{array}{c}2.881 \\
\pm \\
0.055 \\
\end{array}$ & $\begin{array}{c}1.602 \\
\pm \\
0.234 \\
\end{array}$ \\
\hline
\end{tabular}

Values are expressed as mean gram weight \pm S.E. (number of animals per group $=8$ ). Bodyweight or absolute weights of the organs of the treated groups are not significantly different from G1 at $5 \%$ probability level (ANOVA). Bodyweight or absolute weights of the organs of G4R are not significantly different from G1R at $5 \%$ probability level (Students ' $\mathrm{t}$ ' - test). 
Table.3 Summary of Absolute Organ Weight Of Females

\begin{tabular}{|c|c|c|c|c|c|c|c|c|c|}
\hline GROUP & $\begin{array}{c}\text { Body } \\
\text { Weight }\end{array}$ & Brain & Liver & Spleen & Heart & Adrenals & Gonads & Lungs & Uterus \\
\hline $\begin{array}{c}\text { G1 } \\
\text { (Formulation buffer) }\end{array}$ & $\begin{array}{c}237.125 \\
\pm \\
0.990 \\
\end{array}$ & $\begin{array}{c}1.884 \\
\pm \\
0.039 \\
\end{array}$ & $\begin{array}{c}9.048 \\
\pm \\
0.254 \\
\end{array}$ & $\begin{array}{c}0.453 \\
\pm \\
0.012 \\
\end{array}$ & $\begin{array}{c}0.871 \\
\pm \\
0.029 \\
\end{array}$ & $\begin{array}{c}0.058 \\
\pm \\
0.004 \\
\end{array}$ & $\begin{array}{c}0.119 \\
\pm \\
0.006 \\
\end{array}$ & $\begin{array}{c}1.389 \\
\pm \\
0.063 \\
\end{array}$ & $\begin{array}{c}0.318 \\
\pm \\
0.039 \\
\end{array}$ \\
\hline $\begin{array}{c}\text { G2 } \\
(\text { Etanercept } @ 5.2 \mathrm{mg} / \mathrm{kg} \\
\text { b.w })(1 \times \text { HED })\end{array}$ & $\begin{array}{c}230.375 \\
\pm \\
1.936 \\
\end{array}$ & $\begin{array}{c}1.918 \\
\pm \\
0.030 \\
\end{array}$ & $\begin{array}{c}8.575 \\
\pm \\
0.224\end{array}$ & $\begin{array}{c}0.427 \\
\pm \\
0.008 \\
\end{array}$ & $\begin{array}{c}0.853 \\
\pm \\
0.017 \\
\end{array}$ & $\begin{array}{c}0.057 \\
\pm \\
0.002 \\
\end{array}$ & $\begin{array}{c}0.116 \\
\pm \\
0.005\end{array}$ & $\begin{array}{c}1.386 \\
\pm \\
0.042 \\
\end{array}$ & $\begin{array}{c}0.333 \\
\pm \\
0.021 \\
\end{array}$ \\
\hline $\begin{array}{c}\text { G3 } \\
\text { (Etanercept @ 26mg/kg } \\
\text { b.w.) } \\
(5 \times \text { HED }) \\
\end{array}$ & $\begin{array}{c}232.250 \\
\pm \\
1.031 \\
\end{array}$ & $\begin{array}{c}1.899 \\
\pm \\
0.025\end{array}$ & $\begin{array}{c}8.694 \\
\pm \\
0.104 \\
\end{array}$ & $\begin{array}{c}0.448 \\
\pm \\
0.009 \\
\end{array}$ & $\begin{array}{c}0.846 \\
\pm \\
0.019 \\
\end{array}$ & $\begin{array}{c}0.055 \\
\pm \\
0.002 \\
\end{array}$ & $\begin{array}{c}0.115 \\
\pm \\
0.005 \\
\end{array}$ & $\begin{array}{c}1.506 \\
\pm \\
0.077 \\
\end{array}$ & $\begin{array}{c}0.362 \\
\pm \\
0.030 \\
\end{array}$ \\
\hline $\begin{array}{c}\text { G4 } \\
\text { (Etanercept @ 52mg/kg } \\
\text { b.w.) } \\
(10 \times \text { HED }) \\
\end{array}$ & $\begin{array}{c}228.500 \\
\pm \\
1.535 \\
\end{array}$ & $\begin{array}{c}1.920 \\
\pm \\
0.029 \\
\end{array}$ & $\begin{array}{c}9.264 \\
\pm \\
0.169 \\
\end{array}$ & $\begin{array}{c}0.459 \\
\pm \\
0.005 \\
\end{array}$ & $\begin{array}{c}0.888 \\
\pm \\
0.017 \\
\end{array}$ & $\begin{array}{c}0.061 \\
\pm \\
0.002 \\
\end{array}$ & $\begin{array}{c}0.132 \\
\pm \\
0.007 \\
\end{array}$ & $\begin{array}{c}1.471 \\
\pm \\
0.086 \\
\end{array}$ & $\begin{array}{c}0.378 \\
\pm \\
0.031 \\
\end{array}$ \\
\hline $\begin{array}{c}\text { G1R } \\
\text { (Formulation buffer) }\end{array}$ & $\begin{array}{c}244.750 \\
\pm \\
1.359 \\
\end{array}$ & $\begin{array}{c}1.909 \\
\pm \\
0.031 \\
\end{array}$ & $\begin{array}{c}8.602 \\
\pm \\
0.272 \\
\end{array}$ & $\begin{array}{c}0.451 \\
\pm \\
0.018 \\
\end{array}$ & $\begin{array}{c}0.802 \\
\pm \\
0.023\end{array}$ & $\begin{array}{c}0.071 \\
\pm \\
0.003\end{array}$ & $\begin{array}{c}0.126 \\
\pm \\
0.005\end{array}$ & $\begin{array}{c}1.453 \\
\pm \\
0.091\end{array}$ & $\begin{array}{c}0.315 \\
\pm \\
0.035\end{array}$ \\
\hline $\begin{array}{c}\text { G4 } \\
\text { (Etanercept @ 52mg/kg } \\
\text { b.w.) } \\
(10 \times \text { HED })\end{array}$ & $\begin{array}{c}234.875 \\
\pm \\
1.884\end{array}$ & $\begin{array}{c}1.923 \\
\pm \\
0.038\end{array}$ & $\begin{array}{l}8.440 \\
\pm \\
\pm .200\end{array}$ & $\begin{array}{l}0.441 \\
\pm \\
0.015\end{array}$ & $\begin{array}{l}0.785 \\
\pm \\
0.014\end{array}$ & $\begin{array}{c}0.066 \\
\pm \\
0.004\end{array}$ & $\begin{array}{l}0.120 \\
\pm \\
0.006\end{array}$ & $\begin{array}{c}1.408 \\
\pm \\
0.068\end{array}$ & $\begin{array}{c}0.320 \\
\pm \\
0.026\end{array}$ \\
\hline
\end{tabular}

Values are expressed as mean gram weight \pm S.E. (number of animals per group $=8$ ). Bodyweight or absolute weights of the organs of the treated groups are not significantly different from G1 at $5 \%$ probability level (ANOVA). Bodyweight or absolute weights of the organs of G4R are not significantly different from G1R at $5 \%$ probability level (Students ' $t$ ' - test). 
Table.4 Summary of Gross Pathology Findings

\begin{tabular}{|c|c|c|c|c|c|c|c|c|c|c|c|c|}
\hline $\begin{array}{l}\text { Group } \\
\text { Dosage }\end{array}$ & (For & $\begin{array}{l}\text { ation } \\
\text { r) }\end{array}$ & $\begin{array}{r}(\mathbf{E t} \\
@ 5 \\
\text { b.w) }\end{array}$ & $\begin{array}{l}\text { cept } \\
\text { g/kg } \\
\text { IED) }\end{array}$ & $\begin{array}{r}\text { (Eta } \\
26 \mathrm{~m} \\
(5\end{array}$ & $\begin{array}{l}\text { pt @ } \\
\text { o.w.) } \\
\text { )) }\end{array}$ & $\begin{array}{r}\text { Eta } \\
52 \mathrm{~m} \\
(10\end{array}$ & $\begin{array}{l}\text { pt @ } \\
\text { b.w.) } \\
\text { D) }\end{array}$ & $\begin{array}{r}\text { (For } \\
\text { b }\end{array}$ & $\begin{array}{l}\text { ition } \\
\text { ) }\end{array}$ & $\begin{array}{r}\text { Eta } \\
52 \mathrm{n} \\
(1\end{array}$ & $\begin{array}{l}\text { pt @ } \\
\text { b.w) } \\
\text { D) }\end{array}$ \\
\hline No. of animals & 8 & 8 & 8 & 8 & 8 & 8 & 8 & 8 & 8 & 8 & 8 & 8 \\
\hline Sex & $\mathbf{M}$ & $\mathbf{F}$ & $\mathbf{M}$ & $\mathbf{F}$ & $\mathbf{M}$ & $\mathbf{F}$ & $\mathbf{M}$ & $\mathbf{F}$ & $\mathbf{M}$ & $\mathbf{F}$ & $\mathbf{M}$ & $\mathbf{F}$ \\
\hline External and Interna & mina & & & & & & & & & & & \\
\hline LIVER & & & & & & & & & & & & \\
\hline White foci, linear & $1 *$ & 0 & 0 & 0 & 0 & 0 & 0 & 0 & 0 & 0 & 0 & 0 \\
\hline Diaphragmatic nodule & 0 & 0 & 1 & 0 & 0 & 0 & 1 & 0 & 0 & 0 & 0 & 0 \\
\hline KIDNEYS & & & & & & & & & & & & \\
\hline Enlarged, unilateral & 1 & 0 & 0 & 0 & 1 & 1 & 0 & 0 & 0 & 0 & 0 & 0 \\
\hline
\end{tabular}


Table.5 Summary of Histopathology Findings

\begin{tabular}{|c|c|c|c|c|c|c|c|c|c|c|c|c|}
\hline \multirow{3}{*}{$\begin{array}{l}\text { Group } \\
\text { Dosage } \\
\text { No. of animals } \\
\text { Sex }\end{array}$} & \multicolumn{2}{|c|}{$\begin{array}{c}\text { G1 } \\
\text { (Formulation } \\
\text { buffer) }\end{array}$} & \multicolumn{2}{|c|}{$\begin{array}{c}\text { G2 } \\
\text { (Etanercept } \\
@ 5.2 \mathrm{mg} / \mathrm{kg} \\
\text { b.w) (1x } \\
\text { HED) }\end{array}$} & \multicolumn{2}{|c|}{$\begin{array}{c}\text { G3 } \\
\text { (Etanercept @ } \\
26 \text { mg/kg b.w.) } \\
\text { (5× HED) }\end{array}$} & \multicolumn{2}{|c|}{$\begin{array}{c}\text { G4 } \\
\text { (Etanercept @ } \\
52 \text { mg/kg b.w.) } \\
(10 \times \text { HED) }\end{array}$} & \multicolumn{2}{|c|}{$\begin{array}{l}\text { G1R } \\
\text { Formulation } \\
\text { buffer) }\end{array}$} & \multicolumn{2}{|c|}{$\begin{array}{c}\text { G4R } \\
\text { (Etanercept @ } \\
52 \text { mg/kg b.w) } \\
(10 \times \text { HED) }\end{array}$} \\
\hline & 8 & 8 & 8 & 8 & 8 & 8 & 8 & 8 & 8 & 8 & 8 & 8 \\
\hline & $\mathbf{M}$ & $\mathbf{F}$ & $\mathbf{M}$ & $\mathbf{F}$ & $\mathbf{M}$ & $\mathbf{F}$ & $\mathbf{M}$ & $\mathbf{F}$ & $\mathbf{M}$ & $\mathbf{F}$ & $\mathbf{M}$ & $\mathbf{F}$ \\
\hline \multicolumn{13}{|l|}{ LIVER } \\
\hline $\begin{array}{l}\text { Cholangiofibrosis with oval cell } \\
\text { proliferation }\end{array}$ & 1 & 0 & $\#$ & \# & \# & \# & 0 & 0 & $\#$ & \# & $\#$ & $\#$ \\
\hline Diaphragmatic nodule & 0 & 0 & 1 & \# & $\#$ & \# & 1 & 0 & $\#$ & \# & \# & \# \\
\hline \multicolumn{13}{|l|}{ KIDNEYS } \\
\hline Hydronephrosis & 1 & 0 & $\#$ & \# & 1 & 1 & 0 & 0 & $\#$ & \# & $\#$ & \# \\
\hline Cortical cyst & 0 & 1 & $\#$ & \# & $\#$ & \# & 0 & 0 & $\#$ & \# & $\#$ & $\#$ \\
\hline Cystic tubule & 0 & 1 & $\#$ & \# & $\#$ & \# & 0 & 0 & $\#$ & \# & $\#$ & \# \\
\hline \multicolumn{13}{|l|}{ LUNGS } \\
\hline Pneumonitis & 1 & 0 & \# & \# & $\#$ & \# & 0 & 0 & $\#$ & \# & $\#$ & \# \\
\hline Intimal proliferation & 1 & 0 & $\#$ & \# & $\#$ & \# & 0 & 0 & $\#$ & $\#$ & $\#$ & $\#$ \\
\hline Inflammatory cell foci & 1 & 0 & $\#$ & \# & $\#$ & \# & 0 & 0 & $\#$ & \# & $\#$ & \# \\
\hline Inflammatory cell infiltration & 0 & 0 & $\#$ & \# & $\#$ & \# & 1 & 0 & $\#$ & \# & $\#$ & \# \\
\hline \multicolumn{13}{|l|}{ HEART } \\
\hline Cartilagenous metaplasia & 1 & 0 & $\#$ & \# & \# & \# & 0 & 1 & $\#$ & \# & $\#$ & \# \\
\hline \multicolumn{13}{|l|}{ ADRENALS } \\
\hline Accessory cortical nodule & 1 & 0 & $\#$ & \# & $\#$ & \# & 0 & 0 & $\#$ & \# & $\#$ & \# \\
\hline $\begin{array}{l}\text { Cytoplasmic vacuolation, } \\
\text { zonafasciculata, focal }\end{array}$ & 0 & 0 & \# & \# & \# & \# & 0 & 1 & $\#$ & \# & \# & $\#$ \\
\hline
\end{tabular}

* Note: Number of animals having that particular gross pathology finding; M - Male; F - Female; \# - Microscopic examination not performed 
Table.5 Summary of Histopathology Findings (Continued)

\begin{tabular}{|c|c|c|c|c|c|c|c|c|c|c|c|c|}
\hline \multirow{3}{*}{$\begin{array}{l}\text { Group } \\
\text { Dosage } \\
\text { No. of animals } \\
\text { Sex }\end{array}$} & \multicolumn{2}{|c|}{$\begin{array}{c}\text { G1 } \\
\text { (Formulation } \\
\text { buffer) }\end{array}$} & \multicolumn{2}{|c|}{$\begin{array}{c}\text { G2 } \\
\text { (Etanercept } \\
\text { @ 5.2 mg/kg } \\
\text { b.w) (1x } \\
\text { HED) }\end{array}$} & \multicolumn{2}{|c|}{$\begin{array}{c}\text { G3 } \\
\text { (Etanercept } \\
\text { @ } 26 \text { mg/kg } \\
\text { b.w.) } \\
\text { (5× HED) }\end{array}$} & \multicolumn{2}{|c|}{$\begin{array}{c}\text { G4 } \\
\text { (Etanercept @ } \\
52 \text { mg/kg b.w.) } \\
\text { (10× HED) }\end{array}$} & \multicolumn{2}{|c|}{$\begin{array}{c}\text { G1R } \\
\text { (Formulatio } \\
\text { n buffer) }\end{array}$} & \multicolumn{2}{|c|}{$\begin{array}{c}\text { G4R } \\
\text { (Etanercept @ } \\
52 \text { mg/kg b.w) } \\
\text { (10× HED) }\end{array}$} \\
\hline & 8 & 8 & 8 & 8 & 8 & 8 & 8 & 8 & 8 & 8 & 8 & 8 \\
\hline & M & $\mathbf{F}$ & M & $\mathbf{F}$ & M & $\mathbf{F}$ & $\mathbf{M}$ & $\mathbf{F}$ & M & $\mathbf{F}$ & $\mathbf{M}$ & $\mathbf{F}$ \\
\hline \multicolumn{13}{|l|}{ THYMUS } \\
\hline Thymic cyst & 1 & 0 & $\#$ & \# & \# & $\#$ & 0 & 0 & $\#$ & $\#$ & $\#$ & $\#$ \\
\hline \multicolumn{13}{|l|}{ CAECUM } \\
\hline Lymphoid hyperplasia & 2 & 0 & \# & \# & \# & $\#$ & 0 & 0 & \# & \# & \# & \# \\
\hline \multicolumn{13}{|l|}{ COLON } \\
\hline Lymphoid hyperplasia & 2 & 1 & $\#$ & $\#$ & $\#$ & \# & 0 & 0 & $\#$ & $\#$ & $\#$ & $\#$ \\
\hline \multicolumn{13}{|l|}{ URINARY BLADDER } \\
\hline Colloid plug & 1 & 0 & $\#$ & $\#$ & $\#$ & \# & 0 & 0 & $\#$ & $\#$ & $\#$ & \# \\
\hline \multicolumn{13}{|l|}{ UTERUS } \\
\hline Distended & NA & 1 & \# & \# & \# & \# & NA & 1 & \# & \# & \# & \# \\
\hline
\end{tabular}


It is secreted by histiocytes, T lymphocytes, B lymphocytes, Natural Killer cells, mast cells, cells of lining endothelium, fibrocytes as well as neurons. The production of TNF cytokines is highly influenced by the presence of several pro-inflammatory stimuli like lipopolysaccharides (LPS), microbial factors and interleukin-1 beta (Locksley et al., 2001; Aggarwal et al., 2011). It exerts several proinflammatory effects including coordinating the different phases of inflammation by activating inflammatory genes like IL-1, IL-6 and stimulation of its own synthesis (Gordon et al., 1992).

Biopharmaceuticals signify important advances in therapeutical management for several unmet needs and there has been a tremendous increase in the utilization of biotechnological applications in improving several marketed preparations by the conventional pharmaceutical companies. The major issues of safety of biopharmaceuticals are (1) toxicity per se (i.e., the intrinsic toxicity), (2) toxicity due to pharmacodynamics of them (exaggerated pharmacology), and (3) the adverse effects caused by indirect physiological effects independent of their pharmacodynamics. Safety assessment is an important process of the attempt during the discovery of biopharmaceuticals. Generally, these studies are conducted in two species (one non-rodent) for a minimum duration of 2 weeks that would generally support the clinical development trial of up to 2 weeks in duration (FDA, 2010). In the present study, the recombinant etanercept was administered to the Spargue Dawley rats through subcutaneous route on every $3^{\text {rd }}$ day (weekly twice) for 28 days. To identify the reversibility of the adverse reaction a reversal group treated at high dose was maintained without treatment for next 14 days (i.e. 42 days of total experimental period) along with a concurrent control group.
No clinical signs of toxicity and mortality were observed in the test substance groups of rats (G2, G3, G4 and G4R) during the entire observation period. Males and females of different groups showed significant changes in body weights and feed consumption at some time points of the observation period. As these changes were not consistent it cannot be related to test substance. Functional observational battery performed on all the animals from control, treated and reversal groups showed significant difference in foot splay, rectal temperature on few days during the observation period. As these changes were not consistent it cannot be related to test substance. Hematology and biochemical examination performed did not show any significant differences in animals belonging to group (G2, G3 and G4) test substance compared with control (G1) and G4R compared with G1R. Gross pathology examination did not show any test substance related macroscopic findings in all the treated groups. Histopathological examination conducted on control and treated groups did not show any test substance related microscopic findings. As the test substance did not produce any significant adverse effect, the high dose i.e. $52 \mathrm{mg} / \mathrm{kg}$ b.w. could be considered as no-observed-adverse-effect level (NOAEL) for etanercept in the Sprague Dawley rats through subcutaneous route.

\section{References}

Aggarwal BB, Gupta SC, Kim JH (2011). Historical perspectives on tumor necrosis factor and its superfamily: 25 years later, a golden journey. Blood. 119(3):651-665.

Bradley JR (2008). TNF-mediated inflammatory disease. J Pathol214:149160.

FDA (2010). Guidance for Industry M3(R2) Nonclinical Safety Studies for the Conduct of Human Clinical Trials and 
Marketing Authorization for Pharmaceuticals.

https://www.fda.gov/downloads/drugs/g uidances/ucm073246.pdf. Accessed on 16th August 2017.

Gordon HM, Kucera G, Salvo R, Boss JM (1992). TNF induces genes involved in inflammation, cellular and tissue repair, and metabolism in murine fibroblasts. J Immunol148:4021-4027.

Haraoui B, Bykerk V (2007). Etanercept in the treatment of rheumatoid arthritis.

TherClin Risk Manag 3(1):99.

ICH (2011). S6 (R1) - Preclinical safety evaluation of biotechnology derived pharmaceuticals. http://www.ich.org. Accessed on 9th August, 2017.

Levine B, Kalman J, Mayer L, Fillit HM, Packer M (1990). Elevated circulating levels of tumor necrosis factor in severe chronic heart failure. New Eng J Med 323(4):236-241.

Locksley RM, Killeen N, Lenardo MJ (2001). The TNF and TNF receptor superfamilies: integrating mammalian biology. Cell 104(4):487-501.

Lynch CM, Hart BW, Grewal IS (2009). Practical considerations for nonclinical safety evaluation of therapeutic monoclonal antibodies. MAbs. 1(1):211.

Martin PL, Bugelski PJ (2012). Concordance of preclinical and clinical pharmacology and toxicology of monoclonal antibodies and fusion proteins: soluble targets Brit J Pharm 166:806-822.

Meena S, Rinaldi N, Mertsching E, Hutto D (2008). Selection of relevant species.

In: Preclinical Safety Evaluation of Biopharmaceuticals a Science-based Approach to Facilitating Clinical Trials. Cavagnaro JA (ed). John Wiley \& Sons, Inc., USA. 311- 336.

Mohler KM, Torrance DS, Smith CA,
Goodwin RG, Stremler KE, Fung VP, Madani H, Widmer MB (1993). Soluble tumor necrosis factor (TNF) receptors are effective therapeutic agents in lethal endotoxemia and function simultaneously as both TNF carriers and TNF antagonists. $J$ Immunol151:1548-1561.

Natanson CH, Eichenholz PW, Danner RL, Eichacker PQ, Hoffman WD, Kuo GC, Banks SM, MacVittie TJ, Parrillo JE (1989). Endotoxin and tumor necrosis factor challenges in dogs simulate the cardiovascular profile of human septic shock. J.Exp.Med 169(3): 823-832.

Saxne T, Palladino MA, Heinegard D, Talal N, Wollheim FA (1988). Detection of tumor necrosis factor $\alpha$ but not tumor necrosis factor $\beta$ in rheumatoid arthritis synovial fluid and serum. Arthritis Rheum 31(8): 1041-1045.

Sharief MK, Hentges, R (1991). Association between tumor necrosis factor and disease progression in patients with multiple sclerosis.New Eng $J$ Med325:467-472.

Straub RH, Schradin C (2016). Chronic inflammatory systemic diseases - an evolutionary trade-off between acutely beneficial but chronically harmful programs. Evol Med Public Health2016(1):37-51.

Walsh G (2010). Biopharmaceutical benchmarks. Nat Biotechnol28:917-924.

Weinblatt ME, Kremer JM, Bankhurst AD, Bulpitt KJ, Fleischmann RM, Fox RI, Jackson CG, Lange M, Burge DJ (1999). A trial of etanercept, a recombinant tumor necrosis factor receptor: $\mathrm{Fc}$ fusion protein, in patients with rheumatoid arthritis receiving methotrexate. N Eng J Med340(4):253259. 
How to cite this article:

Selvam, G., S. Bhuvana, P.C. Prabu and Sadasivan Pillai, K. 2020. Safety Evaluation of an Anti-Tumor Necrosis Factor-Alpha Receptor Fusion Protein in Sprague Dawley Rats. Int.J.Curr.Microbiol.App.Sci. 9(06): 4256-4272. doi: https://doi.org/10.20546/ijcmas.2020.906.500 